\title{
DETERMINATION OF THE EFFECTS OF DAILY LIFE ACTIVITIES AND SELF-CARE CAPACITY ON DEPRESSION OF THE ELDERLY IN NORTHERN TURKEY
}

\author{
Zeliha Koç and Zeynep Sağlam
}

\author{
Ondokuz Mayis University Health Science Faculty, Kurupelit, Samsun, Turkey
}

\begin{abstract}
SUMMARY - This study aimed to determine the effects of daily living activities and self-care capacity on depression of the elderly in northern Turkey. The study was conducted with participation of 451 voluntary elderly individuals. Data were collected via a questionnaire, Geriatric Depression Scale, Exercise of Self-care Agency Scale, Daily Activities Index, and Instrumental Activities of Daily Living Index. The mean Exercise of Self-care Agency Scale score and Geriatric Depression Scale score was $91.44 \pm 16.32$ and $11.87 \pm 5.01$, respectively. Negative and highly statistically significant correlations $(\mathrm{p}=0.000)$ were found between depression scores and self-care capacity scores $(\mathrm{r}=-0.470)$, daily activities scores $(\mathrm{r}=-0.351)$, and Instrumental Activity of Daily Life scores $(\mathrm{r}=-0.270)$. Study results showed that depression scores of the elderly increased as their daily life activities and self-care capacity scores decreased.
\end{abstract}

Key words: Activities of daily living; Depression; Aged; Nursing; Self care; Turkey

\section{Introduction}

In 2000, 600 million people were aged 60 and over, and by 2050 , there will be 2 billion ${ }^{1}$. As in the world ${ }^{2}$, in Turkey, the aged population is gradually increasing. According to Turkish State Institute of Statistics census findings, the proportion of the population aged 65 and above was $4.3 \%$ in $1990,4.7 \%$ in 1997 , and $5.6 \%$ in 2000. This curve is anticipated to reach $7.7 \%$ in $2020^{3}$. Based on the State Institute of Statistics data, it is clear that Turkey will soon be one of the old countries in the world.

Elderly people need to possess sufficient self-care capacity. Self-care capacity involves the activities conducted by individuals to maintain their independence, lifestyle, and state of health and wellness. Changes in age, health, physical and psychological factors, envi-

Correspondence to: Assoc. Prof. Zeliha Koç, PhD, Ondokuz Mayis University Campus, Kurupelit, Samsun, Turkey

E-mail: zelihaceren@hotmail.com

Received September 2, 2015, accepted October 22, 2017 ronmental conditions, and socio-economic factors can influence the self-care capacity of individuals ${ }^{4,5}$. The literature suggests that physical health, functional limitations and disability are affected by many factors, one of which is depression ${ }^{6-8}$.

Depression has been documented as one of the most prevalent mental health problems in the elder$1 y^{9,10}$. The literature also indicates that depression increases disability ${ }^{11,12}$, morbidity, mortality, and healthcare utilization ${ }^{11}$. Studies have determined that the following factors are related with the development of depression: being female; being single, divorced, or separated ${ }^{10}$; having a low income or socio-economic leve ${ }^{10}$; and having many chronic diseases, insufficient social support, and unexpected negative life events ${ }^{13}$. It has also been reported that depression is an important risk factor for dependency in the elderly ${ }^{14-17}$. In spite of the availability of studies on the factors affecting daily life activities and self-care capacity of the elderly ${ }^{5,18-21}$, no comprehensive study determining the effect of daily life activities and self-care capacity levels on depression in the elderly was found. 
Aims

This descriptive study aimed to determine the effect of daily life activities and self-care capacity levels on depression in the elderly. The questions posed in the study were the following:

1. What is the mean level of depression among elderly individuals?

2. In terms of activities of daily living, are elderly dependent on others?

3. Do daily life activities and self-care capacity levels of the elderly affect depression levels?

\section{Subjects and Methods}

\section{Study design}

This study was conducted between July 1,2013 and December 31, 2013. The authors aimed to recruit the entire population of those presenting to internal medicine and surgical outpatient clinics at Ondokuz Mayss University due to various health problems. A total of 608 elderly individuals were admitted to outpatient clinics during the study period. However, elderly people who were not willing to participate in the study and who did not complete the questionnaire were excluded from the research $(n=157)$. The study was carried out with voluntary participation of 451 elderly individuals. The response rate was $74.2 \%$.

\section{Instruments}

Study data were collected via a questionnaire, Geriatric Depression Scale, Exercise of Self-Care Agency Scale, Daily Activities Index, and Instrumental Activities of Daily Living Index. Both depression and dementia affect activities of daily living (ADLs) and selfcare agency in the elderly. For these reasons, distinction between dementia and depression symptoms was made by questioning the year, season, month, day, country, and city orientations among the elderly.

The Geriatric Depression Scale is an assessment tool introduced by Yesavage $\mathrm{et} \mathrm{al.}{ }^{22}$. Its validity and reliability for Turkish population has been verified by Ertan and Eker ${ }^{23}$. The scale consists of 30 self-report questions aimed at enabling the elderly to respond easily with 'yes' or 'no'. The minimal and maximal number of points that can be obtained on the scale is 1 and 30, respectively. The Geriatric Depression Scale Cronbach Alpha reliability coefficient was determined to be 0.77 .
The validity and reliability of the Exercise of SelfCare Agency Scale developed by Kearner and Fleisch$\mathrm{er}^{24}$ were tested in Turkey by Nahçivan ${ }^{25}$. The scale employs self-evaluations of self-care activities. Each statement is rated from 0 to 4 , and the ratings are based on a five-point Likert-type scale. A higher score obtained using the scale indicates greater self-care potential ${ }^{25}$. The Exercise of Self-Care Agency Scale Cronbach Alpha reliability coefficient was determined to be 0.81 .

The Daily Activities Index was used to detect problems in performing ADLs. Clients receive a score of yes/no for independence in bathing, dressing, toileting, transferring, continence, and feeding ${ }^{26,27}$. The Daily Activities Index Cronbach Alpha reliability coefficient was determined to be 0.89 .

The Instrumental Activities of Daily Living Index includes preparing meals, shopping, taking medicine, traveling out of walking distance, doing housework, performing repairs in the house, managing money, and using telephone. The activities of the participants are evaluated as independent, semi-independent or dependent. The Instrumental Activities of Daily Living Index Cronbach Alpha reliability coefficient was determined to be 0.91 .

\section{Data collection}

Data were collected from the elderly over a period of six months by the researcher during face-to-face interviews. This study was conducted in accordance with the principles of the Helsinki Declaration (WMA Declaration of Helsinki, 2008 ${ }^{28}$. The questionnaire was tested on a group of 10 elderly individuals in a pilot study. The response time was 20-25 min.

\section{Data analysis}

Data were analyzed using SPSS for Windows (v. 15.0). Descriptive statistics and Student's t-tests were used to summarize data. Multiple regression analysis was used to determine whether there was a difference between depression scores of the elderly regarding self-care capacity, daily life activity, and instrumental activities of daily living. The values of $\mathrm{p}<0.05$ were considered statistically significant.

\section{Results}

In this study, $35.9 \%$ of all participants were between 60 and 66 years of age, $44.8 \%$ were females and 
55.2\% were males (Table 1). According to the distribution of clinical characteristics, $65.0 \%$ of all participants suffered from chronic diseases. Moreover, daily life activities were affected by chronic diseases in $94.2 \%$ of the participants, $21.3 \%$ exercised, $10.4 \%$ smoked, and $28.4 \%$ attended social activities (Table 2). The mean participants' Exercise of Self-Care Agency Scale score and Geriatric Depression Scale score was $91.44 \pm 16.32$ and $11.87 \pm 5.01$, respectively. Additionally, $25.5 \%$ of the participants were dependent in terms of Daily Life Activities and 8.0\% in terms of Instrumental Activities of Daily Living.

The current study revealed that the mean self-care capacity scores were relatively higher in married $(\mathrm{t}=2.881, \mathrm{p}=0.004)$, regular health check-up receiving $(\mathrm{t}=4.174, \mathrm{p}=0.000)$ and exercising $(\mathrm{t}=6.088, \mathrm{p}=0.000)$ elderly individuals. The mean depression scores were also higher in women $(\mathrm{t}=4.915, \mathrm{p}=0.000)$, singles $(t=5.123, p=0.000)$, chronic disease sufferers $(t=4.849$, $\mathrm{p}=0.000)$ and those that did not attend social activities $(t=4.857, p=0.000)$. There was a significant negative relationship between the depression scale score and educational status $(r=-0.176)$, perception of health $(r=-$ $0.423)$ and satisfaction with medical treatment received $(r=-0.286)$, and a significant positive relationship between the state of having a chronic disease $(r=0.095)$ and the depression scale score $(\mathrm{p}<0.000)$ for the elderly. In other words, the mean score of depression decreased with increase in the level of education, level of health perception and level of satisfaction with medical treatment. Nevertheless, having a chronic disease increased the depression score.

The present study also revealed a statistically significant correlation $(\mathrm{p}<0.000)$ between the participants' mean scores on the Daily Life Activities and Instrumental Activities of Daily Living Indexes and certain socio-demographic and clinical characteristics. The Daily Life Activities Index scores were higher in men $(t=7.777, p=0.000)$, married individuals $(t=3.425$, $\mathrm{p}=0.001)$, individuals receiving regular health checkups $(\mathrm{t}=3.488, \mathrm{p}=0.001)$, individuals attending social activities $(\mathrm{t}=3.179, \mathrm{p}=0.002)$ and individuals who exercised $(t=5.857, p=0.000)$. Moreover, the Instrumental Activities of Daily Living Index scores were higher in men $(\mathrm{t}=7.374, \mathrm{p}=0.000)$, married individuals $(\mathrm{t}=2.432$, $\mathrm{p}=0.015)$, individuals without a chronic disease $(\mathrm{t}=2.344, \mathrm{p}=0.020)$, individuals attending social activi-
Table 1. Distribution of elderly subjects according to socio-demographic characteristics $(N=451)$

\begin{tabular}{|c|c|c|}
\hline Characteristic & $\mathrm{n}$ & $\%$ \\
\hline Age group (yrs, mean \pm SD) & $69.1 \pm 6.7$ & \\
\hline $60-66$ & 162 & 35.9 \\
\hline $67-73$ & 147 & 32.6 \\
\hline $74-80$ & 95 & 21.1 \\
\hline $81-87$ & 47 & 10.4 \\
\hline \multicolumn{3}{|l|}{ Gender } \\
\hline Female & 202 & 44.8 \\
\hline Male & 249 & 55.2 \\
\hline \multicolumn{3}{|l|}{ Marital status } \\
\hline Married & 395 & 87.6 \\
\hline Single & 56 & 12.4 \\
\hline \multicolumn{3}{|l|}{ Education level } \\
\hline Literate & 270 & 59.9 \\
\hline Elementary school & 143 & 31.7 \\
\hline Intermediate school & 19 & 4.2 \\
\hline High school & 9 & 2.0 \\
\hline University & 10 & 2.2 \\
\hline \multicolumn{3}{|l|}{ Socioeconomic status } \\
\hline Income less than expenses & 212 & 47.0 \\
\hline Income equal to expenses & 229 & 50.8 \\
\hline Income greater than expenses & 10 & 2.2 \\
\hline \multicolumn{3}{|l|}{ Social insurance } \\
\hline Present & 417 & 92.5 \\
\hline Absent & 34 & 7.5 \\
\hline \multicolumn{3}{|l|}{ Occupation } \\
\hline Homemaker & 185 & 41.0 \\
\hline Worker & 99 & 22.0 \\
\hline Officer & 9 & 2.0 \\
\hline Retired & 90 & 20.0 \\
\hline Self-employed & 68 & 15.0 \\
\hline \multicolumn{3}{|l|}{ Place of residence } \\
\hline City & 109 & 24.2 \\
\hline Town & 134 & 29.7 \\
\hline Village & 208 & 46.1 \\
\hline \multicolumn{3}{|l|}{ Family type } \\
\hline Large & 186 & 41.2 \\
\hline Small, nuclear & 265 & 58.8 \\
\hline \multicolumn{3}{|l|}{ Number of children } \\
\hline $1-3$ & 162 & 35.9 \\
\hline $4-6$ & 221 & 49.0 \\
\hline $7-9$ & 64 & 14.2 \\
\hline None & 4 & 0.9 \\
\hline \multicolumn{3}{|l|}{ Lives with } \\
\hline Spouse & 166 & 36.8 \\
\hline Family member(s) & 280 & 62.1 \\
\hline Alone & 5 & 1.1 \\
\hline
\end{tabular}


Table 2. Distribution of elderly subjects according to clinical characteristics and health behavior $(N=451)$

\begin{tabular}{|c|c|c|}
\hline Characteristic & $\mathrm{n}$ & $\%$ \\
\hline \multicolumn{3}{|l|}{ Perceived health } \\
\hline Good & 153 & 33.9 \\
\hline Fair & 250 & 55.4 \\
\hline Poor & 48 & 10.7 \\
\hline \multicolumn{3}{|l|}{$\begin{array}{l}\text { Satisfied with medical } \\
\text { treatment }\end{array}$} \\
\hline Yes & 393 & 87.1 \\
\hline No & 58 & 12.9 \\
\hline \multicolumn{3}{|c|}{$\begin{array}{l}\text { Satisfaction level related to medical } \\
\text { treatment }(n=393)\end{array}$} \\
\hline Low & 8 & 2.0 \\
\hline Middle & 281 & 71.5 \\
\hline High & 104 & 26.5 \\
\hline \multicolumn{3}{|l|}{ Chronic disease condition } \\
\hline Yes & 293 & 65.0 \\
\hline No & 158 & 35.0 \\
\hline \multicolumn{3}{|l|}{${ }^{\mathrm{a}}$ Has chronic illness $(\mathrm{n}=293)$} \\
\hline Coronary arterial disease & 148 & 50.5 \\
\hline Diabetes & 116 & 39.6 \\
\hline Hypertension & 169 & 57.7 \\
\hline Osteoporosis & 14 & 4.8 \\
\hline Asthma & 10 & 3.4 \\
\hline Renal failure & 36 & 12.3 \\
\hline Rheumatism & 8 & 2.7 \\
\hline Herniated disc & 3 & 1.0 \\
\hline Hepatitis & 3 & 1.0 \\
\hline Epilepsy & 4 & 1.4 \\
\hline Goiter & 8 & 2.7 \\
\hline Cataract & 4 & 1.4 \\
\hline
\end{tabular}

\begin{tabular}{|l|l|l|}
\hline Characteristic & $\mathrm{n}$ & $\%$ \\
\hline $\begin{array}{l}\text { Daily activities affected by chronic } \\
\text { illness (n=293) }\end{array}$ & & \\
$\quad$ Yes & 276 & 94.2 \\
No & 17 & 5.8 \\
\hline Previous hospitalization & 389 & 86.3 \\
Yes & 62 & 13.7 \\
No & & \\
\hline Frequency of hospitalization (n=389) & 68 & 17.5 \\
At least once a month & 51 & 13.1 \\
Once in three months & 50 & 12.9 \\
Once in six months & 111 & 28.5 \\
Once a year & 109 & 28.0 \\
Other & & \\
\hline Has an attendant while hospitalized & & \\
(n=389) & 267 & 68.6 \\
Yes & 122 & 31.4 \\
No & & \\
\hline Has regular health check-ups & 288 & 63.9 \\
Yes & 163 & 36.1 \\
No & & \\
\hline Exercises & 96 & 21.3 \\
Yes & 355 & 78.7 \\
No & & \\
\hline Smoking & 47 & 10.4 \\
Yes & 404 & 89.6 \\
No & 128 & 28.4 \\
\hline Attending social activities & 323 & 71.6 \\
\hline Yes & & \\
No & & \\
\hline
\end{tabular}

${ }^{a}$ More than one answer was given.

ties $(\mathrm{t}=2.143, \mathrm{p}=0.033)$ and individuals who exercised $(\mathrm{t}=6.991, \mathrm{p}=0.000)$.

In the regression analysis concerning the effect of the Daily Life Activities and Self-Care Agency and Instrumental Activity of Daily Life on depression (Table 3), a statistically highly significant negative relationship was found between depression scores and self-care capacity of the elderly $(r=-0.470)$, daily life activities ( $\mathrm{r}=-0.351)$, and Instrumental Activity of Daily Life scores $(r=-0.270)$. Study results showed that depression scores of the elderly increased as their daily life activities and self-care capacity scores decreased.

\section{Discussion}

While the extent of depression varies with the characteristics of the elderly group involved in the study, the location of the study, and the selected methods, it has been asserted in the literature that many different factors affect development of depres$\operatorname{sion}^{10,11,29-33}$. This study revealed that the mean depression scores were higher in women, singles, chronic disease sufferers, and individuals who did not attend social activities. Additionally, according to some studies, it has been asserted that depression, in line with the 
Table 3. Multiple regression analysis of factors (self-care capacity, daily life activities and instrumental activities of daily living) affecting depression levels in the elderly

\begin{tabular}{|c|c|c|c|c|c|}
\hline & \multicolumn{3}{|c|}{ Coefficients ${ }^{a}$} & \multirow{3}{*}{$\mathrm{t}$} & \multirow{3}{*}{ Sig. } \\
\hline & \multicolumn{2}{|c|}{$\begin{array}{l}\text { Unstandardized } \\
\text { coefficients }\end{array}$} & \multirow{2}{*}{$\begin{array}{l}\text { Standardized } \\
\text { coefficients } \\
\text { Beta }\end{array}$} & & \\
\hline & $\mathrm{B}$ & SE & & & \\
\hline (Constant) & 25.823 & 1.235 & & 20.910 & 0.000 \\
\hline Self-care capacity & -0.128 & 0.013 & -0.417 & -10.154 & 0.000 \\
\hline Daily life activities & -0.708 & 0.143 & -0.293 & -4.943 & 0.000 \\
\hline Instrumental activities of daily living & 0.039 & 0.055 & 0.042 & 0.701 & 0.484 \\
\hline
\end{tabular}

${ }^{a}$ Dependent variable: depression total points; $\mathrm{SE}$ = standard error; Sig. = significance

current research findings, is more common among women ${ }^{10,21,31,32}$. However, according to other studies inconsistent with the current research findings, depression is more common among individuals with low education levels ${ }^{10,31,32}$ and those living in city centers, having serious illnesses or physical disabilities, physically inactive individuals and smokers ${ }^{31,32}$.

The current study revealed that two-thirds of the elderly had chronic diseases and that depression scores of such individuals were higher. Consistent with the results obtained in this sample, findings of other studies $^{34,35}$ conducted in Turkey on this issue have revealed that elderly individuals with chronic diseases have higher levels of depression. However, in other studies ${ }^{36}$ that have yielded findings inconsistent with the present ones, it has been asserted that having a chronic disease does not have any effect on the level of depression.

The present study found that almost all daily activities in the elderly chronic-disease sufferers were affected by their conditions and one-third of the elderly were dependent on the others in terms of continuing their daily life activities. Relevant studies from other countries $^{37,38}$ have shown that between $4.3 \%$ and $8.6 \%$ of the elderly depend on the others to maintain their activities of daily living. Performing activities of daily living and self-care as part of personal care without any assistance is quite important in the eyes of the elderly.

In this study, it was determined that Daily Life Activity Index scores were relatively lower (and, consequently, dependency levels were higher) in the following: women, singles, and individuals not receiving regular check-ups, not attending social activities, and not exercising. In some studies, it has been asserted that dependency in terms of activities of daily living, in line with the current research findings, is more common among women ${ }^{20,21,39,40}$. However, according to other studies presenting findings inconsistent with those of the current research, dependency in terms of activities of daily living is more common among the following: homemakers ${ }^{20}$, advanced age groups ${ }^{19-21}$, individuals with low education levels ${ }^{19}$, individuals without any social security ${ }^{20}$, individuals with low socioeconomic status ${ }^{20}$, chronic-disease sufferers ${ }^{20,21}$, individuals who constantly use medicine ${ }^{20}$, and individuals who perceive their health status as poor $^{21}$. Jiang et al. report that some demographic subgroups appear to be at a higher risk of impaired ADLs ${ }^{41}$. Almedia and Rodrigues found that women and 75-84 age group were more dependent ${ }^{37}$. Also, Konno et al. report that the prevalence of ADL disability increases with aging ${ }^{38}$.

The present study demonstrated that the mean self-care capacity scores of the elderly were relatively higher in married individuals and among those who received regular health check-ups and exercise. On the other hand, other studies carried out on this issue have asserted that self-care capacity decreases as age and disease duration increase in the elderly ${ }^{20}$, and that decreased self-care capacity has an important effect on the mood state of elderly individuals ${ }^{42}$.

We found negative correlation between Geriatric Depression Scale scores and self-care capacity and daily life activity scores. That is, as daily life activities and self-care capacity decreased, depression levels in the elderly increased. During the aging process, the elderly may find it difficult to carry out the daily activities they were able to perform previously, and they may become dependent on the others. This may affect the elderly at many levels and hence decrease their self- 
care capacity. According to the findings of this study, a decrease in both daily life activities and self-care capacity levels of the elderly had a negative effect on depression. Therefore, reduction of depression prevalence in the elderly is of utmost importance.

\section{Conclusion}

In this study, depression scores of the elderly increased as their daily life activities and self-care capacity scores decreased. Therefore, the following is proposed: support to the elderly people's maintaining daily life activities and self-care capacity independently; carrying out routine depression screenings among the elderly; referring elderly people at risk to psychiatric services and monitor them; and strengthening psychological counseling and guidance services focused on the elderly.

\section{References}

1. WHO 10 facts on ageing and the life course 2012 [Internet]. Department of NCD Prevention \& Health Promotion. World Health Organization. [cited 2012 May 19]. Available from: http://www.who.int/features/factfiles/ageing

2. World Assembly on Ageing II. The ageing of the world's population. May 2001[Internet]. [cited 2012 May 19]. Available from: http://www.globalaging.org/waa2/documents/theagingoftheworld.htm

3. Republic of Turkey Prime Ministry State Institute of Statistics 2000 [Internet]. [cited 2012 May 19]. Available from: http:// www.tuik.gov.tr

4. Fleming KC, Evans JM, Weber DC, Chutka DS. Practical functional assessment of elderly persons: a primary care approach. Mayo Clin Proc. 1995;70(9):890-910.Doi:10.1016/ S0025-6196(11)63949-9

5. Ozer M. To study self-care strength and life satisfaction of elderly persons who reside in rest home and family environment [dissertation]. Ege University Health Science Institution; 2001.

6. Lawrence RH, Jette AM. Disentangling the disablement process. J Gerontol B Psychol Sci Soc Sci. 1996;51(4):173-82. Doi:10.1093/geronb/51b.4.s173

7. Verbrugge LM, Jette AM. The disablement process. Soc Sci Med. 1994;38(1):1-14. Doi:10.1016/0277-9536(94)90294-1

8. Martinac M, Pehar D, Karlovic D, Babic D, Marcinko D, Jakovljevic. Metabolic syndrome, activity of the hypothalamicpituitary-adrenal axis and inflammatory mediators in depressive disorder. Acta Clin Croat. 2014;53:55-7. PMID:24974667

9. Sinanovic O, Hudic J, Zukic S, Kapidzic A, Zonic L, Vidovic M. Depression and dementia in Parkinson's disease. Acta Clin Croat. 2015;54:73-6. PMID:26058246
10. Blazer D, Hughes DC, George LK. The epidemiology of depression in an elderly community. Gerontologist. 1987;27(3): 281-7. Doi:10.1093/geront/27.3.281

11. Alexopoulos GS, Katz IR, Reynolds CF, Carpenter D, Docherty JP, Ross RW. Pharmacotherapy of depression in older patients: a summary of the expert consensus guidelines. J Psychiatr Pract. 2001;7(6):361-76. PMID:15990550

12. Armenian HK, Pratt LA, Gallo J, Eaton WW. Psychopathology as predictor of disability: a population-based follow-up study in Baltimore, Maryland. Am J Epidemiol. 1998;148 (3):269-75. Doi:10.1093/oxfordjournals.aje.a009635

13. Altıntaş H, Atilla S, Sevencan F, Akçalar S, Sevim Y, Solak ÖS, et al. The screening of depression symptoms of the elderly living in a residential home in Ankara. TSK Koruyucu Hekim Bul. 2006;5(5):332-42.

14. Béland F, Zunzunegui MV. Predictors of functional status in older people living at home. Age Ageing. 1999;28(2):153-9. Doi:10.1093/ageing/28.2.153

15. Cho CY, Alessi CA, Cho M, Aronow HU, Stuck AE, Rubenstein LZ, et al. The association between chronic illness and functional change among participants in a comprehensive geriatric assessment program. J Am Geriatr Soc. 1998;46(6): 677-82. Doi:10.1111/j.1532-5415.1998.tb03800.x

16. Rantanen T, Penninx BW, Masaki K, Lintunen T, Foley D, Guralnik JM. Depressed mood and body mass index as predictors of muscle strength decline in old men. J Am Geriatr Soc. 2000;48(6):613-7. Doi:10.1111/j.1532-5415.2000.tb04717.x

17. Stuck AE, Walthert JM, Nikolaus T, Büla CJ, Hohmann C, Beck JC. Risk factors for functional status decline in community-living elderly people: a systematic literature review. Soc Sci Med. 1999;48(4):445-69. Doi:10.1016/s0277-9536(98)00370-0

18. Akgün HS, Bakar C, Budakoğlu II. Health and mental status and daily living activities of 65 years and over hospitalized patients at Başkent University Hospitals network. Turk J Geriatr. 2009;7(3):133-8.

19. Güneş G, Demircioğlu N, Karaoğlu L. Daily living activities, social and psychological function levels of older women living in central Malatya. Turk J Geriatr. 2005;8(2):78-83.

20. Tel H, Tel H, Sabancioğulları S. Status of maintenance of activities of daily living and experience of loneliness in elder than 60 years old living at home and in institutions. Turk J Geriatr. 2006;9(1):34-40.

21. Ulusal B, Soyer A, Uçku R. Dependence in daily living activities among community dwelling elderly: prevalence and risk factors. Turk J Geriatr. 2004;7(4):199-205.

22. Yesavage JA, Brink TL, Rose TL, Lum O, Huang V, Adey M, et al. Development and validation of a geriatric depression screening scale: a preliminary report. J Psychiatr Res. 1983; 17(1):37-49. PMID:7183759

23. Ertan T, Eker E. Reliability, validity and factor structure of the Geriatric Depression Scale in Turkish elderly: are there different factor structures for different cultures? Int Psychogeriatr. 2000;12(2):163-72. PMID:10937537 
24. Kearney BY, Fleischer BJ. Development of an instrument to measure exercise of self-care agency. Res Nurs Health. 1979; 22(1):25-34.https://doi.org/10.1002/nur.4770020105

25. Nahçıvan NO. A Turkish language equivalence of the exercise of self-care agency scale. Western J Nurs Res. 2004;26(7): 813-24. Doi:10.1177/0193945904267599

26. Shelkey M, Wallace M. Katz Index of independence in activities of daily living. J Geron Nursing. 1999;25(3):8-9. Doi: 10.3928/0098-9134-19990301-05

27. Wallace M, Shelkey M. [Internet]. Katz Index of independence in activities of daily living. Issue Number 2, Revised 2007. [cited 2012 May 19]. Available from: http://210.0.231.168/Files/ AlwaysOnLearning/3530Day4_try_this_2_katz_adl.pdf

28. World Medical Association. WMA Declaration of Helsinki: Ethical Principles for Medical Research Involving Human Subjects [Internet]. Seoul, Korea: World Medical Association; 2008. [cited 2012 May 19]. Available from: http://www.wma. net/en/30publications/10policies/b3/

29. Beekman AT, Deeg DJ, Braam AW, Smith JH, Van Tilburg W. Consequences of major and minor depression in later life: a study of disability, well-being and service utilization. Psychol Med.1997;27(6):1397-409. Doi:10.1017/s0033291797005734

30. Chen R, Wei L, Hu Z, Qin X, Copeland JRM, Hemingway H. Depression in older people in rural China. Arch Intern Med. 2005;165(17):2019-25. Doi:10.1001/archinte.165.17.2019

31. Penninx BWJH, Guralnik JM, Ferrucci L, Simonsick EM, Deeg DJH, Wallace RB. Depressive symptoms and physical decline in community-dwelling older persons. JAMA. 1998; 279(21):1720-6. Doi:10.1001/jama.279.21.1720

32. Penninx BWJH, Geerlings SW, Deeg DJH, Van Eijk JTM, Van Tilburg W, Beekman ATF. Minor and major depression and the risk of death in older persons. Arch Gen Psychiatry. 1999;56(10):889-95. Doi:10.1001/archpsyc.56.10.889

33. Van Gool CH, Kempen GIJM, Penninx BWJH, Deeg DJH, Beekman ATF, Van Eijk JTM. Impact of depression on dis- ablement in late middle aged and older persons: results from the Longitudinal Aging Study Amsterdam. Soc Sci Med. 2005;60(1):25-36. Doi:10.1016/j.socscimed.2004.04.021

34. Dişçigil G, Gemalmaz A, Başak O, Gürel FS, Tekin N. Depression in geriatric age group in a primary care setting. Turk J Geriatr. 2005;8(3):129-33.

35. Hacıhasanoğlu R, Yıldırım A. Depression among the elderly in Erzincan Nursing Home and influential factors. Turk J Geriatr. 2009;12(1):25-30.

36. Y⿺ldız A, Erol S, Ergün A. Pain and depression risk among elderly people living in a nursing home. Turk J Geriatr. 2009; 12(3):156-64.

37. Almeida SAJ, Rodrigues, PVMC. The quality of life of aged people living in homes for the aged. Rev Latino-Am Enfermagem. 2008;16(6):1025-31. Doi: 10.1590/S0104-1169200800 0600014

38. Konno K, Katsumata Y, Arai A, Tamashiro H. Functional status and active life expectancy among senior citizens in a small town in Japan. Arch Gerontol Geriatr. 2004;38(2):153-66. PMID:14698494

39. Berberoğlu U, Gül H, Eskiocak M, Ekuklu G, Saltık A. Some socio-demographic specialties and daily activities of the elderly people according to the Katz Index who live in Edirne rest house. Turk J Geriatr. 2002;5(4):144-9.

40. Uçku R, Ergin S. Daily life activity in elderly. Toplum Hekimliği Bülteni. 1993;14(2):1-5.

41. Jiang J, Tang Z, Meng XJ, Futatsuka M. Demographic determinants for change in activities of daily living: a cohort study of the elderly people living in Beijing. J Epidemiol. 2002;12 (3):280-6. Doi:10.2188/jea.12.280

42. Borg C, Hallberg IR, Blomqvist K. Life satisfaction among older people (65+) with reduced self-care capacity: the relationship to social, health and financial aspects. J Clin Nurs. 2006; 15:607-18. Doi:10.1111/j.1365-2702.2006.01375.x

\section{Sažetak \\ UČINAK AKTIVNOSTI SVAKODNEVNOG ŽIVOTA I SPOSOBNOSTI ZA BRIGU O SEBI NA DEPRESIJU KOD STARIJIH OSOBA NA SJEVERU TURSKE}

$$
\text { Z. Koç i Z. Sağlam }
$$

Cilj ovoga istraživanja bio je utvrditi učinke aktivnosti svakodnevnog života i sposobnosti za brigu o sebi na depresiju kod starijih osoba na sjeveru Turske. Istraživanje je provedeno uz dobrovoljno sudjelovanje 451 starije osobe. Podaci su prikupljeni pomoću upitnika i sljedećih ljestvica: Geriatric Depression Scale, Exercise of Self-care Agency Scale, Daily Activities Index i Instrumental Activities of Daily Living Index. Srednji zbir na Exercise of Self-care Agency Scale bio je 91,44 $\pm 16,32$, a na Geriatric

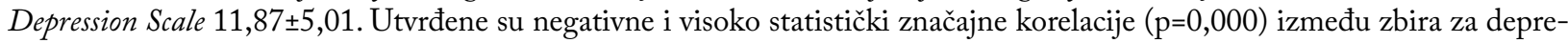
siju sa zbirom sposobnosti za brigu o sebi $(r=-0,470)$ i zbirom aktivnosti svakodnevnog života $(r=-0,351)$. Rezultati istraživanja pokazali su da se zbir za depresiju kod starijih osoba povećava sa snižavanjem zbira svakodnevnih aktivnosti i zbira sposobnosti za brigu o sebi.

Ključne riječi: Dnevne aktivnosti; Depresija; Starija osoba; Sestrinstvo; Samozbrinjavanje; Turska 